\title{
The Development of Wheeled Transpor- tation in Osun Division of Southwestern Nigeria, 1900-1960
}

\author{
AbiodunAjayi \\ Department of History \\ Adeyemi College of Education \\ Ondo \\ Nigeria \\ ajayia@aceondo.edu.ng
}

\begin{abstract}
Wheeled transportation constituted a single factor that facilitated the incorporation of various African communities into the Europeans' mercantile economy. In fact, it was an innovation in Africa where people had relied on some navigable waterways in the coastal areas, park animals in the tsetse flies free areas like Northern Nigeria and trekking along foot paths where human head porterage predominated. However, with the advent of the wheeled transportation technology, economic horizon became broader as people were provided with more profitable endeavors to engage themselves with. This essay attempts to analyze the development of wheeled transportation as a factor that was fundamental to the new developments in colonial Osun Division of Southwestern Nigeria. This is in a view to examine the diplomacies that surrounded road and rail construction in the division, Western Regional Government initiatives and the implications of the transportation technology on the divisional economy. The study depends on oral data gathered through interviews and archival materials as well as literatures that were considered relevant to the subject matter. Considering the shift of attention to the production of cash crops which were more profitable compared to the food crops, availability of new jobs as a result of the movement of the trading firms into the division and massive emigration of able bodied men and women in search of
\end{abstract}


more profitable jobs. There is therefore no doubt that wheeled transportation technology occasioned a transformation that was unprecedented in the colonial economy of Osun Division.

\section{Introduction}

As transport economists have shown, improved transport and communication are indeed fundamental to all types of development; hence they constitute the formative power and the differentiating process of economic growth. ${ }^{1}$ The importance of mechanical transport that is being tagged wheeled transportation infrastructure here, could be seen in the need to quicken the pace of the transition from predominantly subsistent economy to modern exchange economy. ${ }^{2}$ The foregoing is to infer that, although Osun Division that is the focus of this study was not without a form of transportation or another, but road and rail transportation were non-existent and what were available were far from being relevant for the economic transformation the Division was going to undergo in the ensuing years. Construction of roads and rail which were the infrastructures of wheeled transportation therefore had to wait until the first decade of the twentieth century. The implication of the foregoing was that, the area remained inaccessible to European merchants who were keen at reaching the actual sources of cash crops needed by their home industries. ${ }^{3}$

In the meantime, human head porterage and trekking along footpaths took adequate care of the pre-colonial volume of economic activities, but they were far more inadequate for the demand of the capital-intensive economy of the European colonial masters. However, the urgent demand for wheeled transportation and the associated diplomacy of collaboration between the government and the trading companies during the colonial period, authenticated the fact that, British colonial government did not come to Nigeria for a tea party, but to trade and make profits. Colonial government therefore became a partner to expatriate companies through its construction of roads, railway lines and harbors where applicable to facilitate a conducive environment for the companies to operate. ${ }^{4}$

1 . O. Oshin, "Nigerian Railway under Stress 1912-45: A Study in Colonial Transport Planning and Management," ODU: New Series, 37, (January/July, 1990), 49. See also, I.C. Ogwude, "The Impact of a new Road Construction: A Study of the Wukari/Numan Road in Gongola State." (Unpublished Reports, 1980), 7.

2 . S.A. Olanrewaju, "The Infrastructure of Exploitation: Transport, Monetary Changes, Banking, e.t.c." in T. Falola (ed.), Britain and Nigeria: Exploitation or Development?, (London: Zed Books Ltd, 1987), 67.

3 . Atanda, J.A. The New Oyo Empire, (London: Longman Group Ltd. 1979), 217.

4 . A. Afolabi, "The Colonial Taxation Policy among Yoruba of Southwestern Nigeria and its Implications for Socio-Economic Development," Journal of the Historical Society of Nigeria, 19, (2010), 72. 


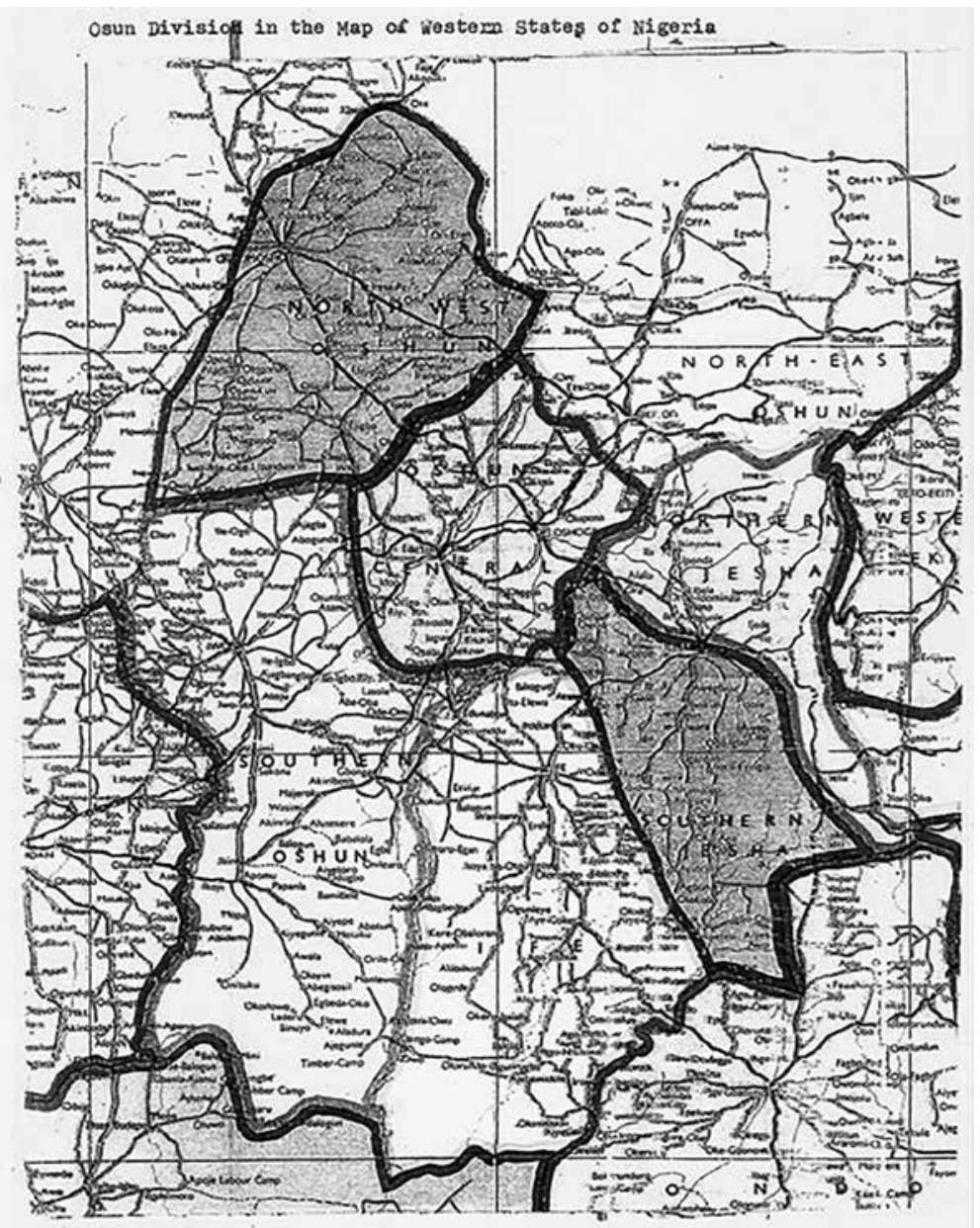

Source: Map Doport; Office of the Surveyor Genoral, Oyo State, Nigeria Map of Osun Division

Improved transportation system in Yorubaland was actually an initiative of the European merchants and a very important instrument they employed in achieving this was lobbying. Incessant pressure was applied on successive native administrations in Yorubaland, as in other parts of Nigeria, between 1885 and 1914 to improve the system of transportation which was also necessary for administrative purpose by way of making the hinterland of Yorubaland accessible for the British administrative officers in the course of their duties. ${ }^{5}$ The hope was that, it would make it convenient to send troops at once

5 . M. Olaniyan, Economic History of West Africa, (Akure: Olaniyan Publishing Company (Nig), Ltd. 1980), 80. 
to possible rebellious groups and ease administration tremendously. ${ }^{6}$ The important roles of a good transportation system in the task of the British administrative officers at that time could therefore, not be over emphasized.

Wheeled transportation as adopted in this study however refers to the duo of road and rail transportation which arrived in Osun Division at the same time as Siemens twins. And as intended by the British, it enhanced the incorporation of the Division into the world capitalist economy and transformed the lifestyle of the people therein. ${ }^{7}$ Osun Division, the area covers by the study is defined as the area occupied by the old Osun administrative division. It was created out of the old Oyo province due to the agitation of the educated elite of the area and the period so chosen covers the colonial era during which the wheeled transportation was introduced into the area. ${ }^{8}$

\section{The Advent of Wheeled Transportation in Osun Division Railway}

The importance of this means of transportation to the British commercial motive in Yorubaland could be seen in the fact that European commercial community in Lagos had to wait for its construction before they could expand their operations into the hinterland. As a matter of fact, it was regarded as the practical answer to the problem of joining the Nigerian coast to its hinterland. ${ }^{9}$ The initiative for the construction of the railways came from the European merchants, particularly the section of the Liverpool and Manchester chambers of commerce. After a series of survey works between 1890 and 1895 on the proper courses and terminals for the railway lines, reports favored railway construction in Yorubaland. This initiative emanated

6 . W. Oyemakinde, "Railway Construction and Operation in Nigeria, 1895-1911: Labour Problems and Socio-Economic Impact." Journal of the Historical Society of Nigeria, Vol. 7, No. 2, (June, 1974), 303.

7 . O. Adegbola, "The Impact of Migration on the Rural Economy of Osun Division of Western Nigeria.” (Ph. D. Thesis. Department of Geography, University of Ibadan, 1972), 37.

8 . A. Ajayi, "Change and Adaptation in the Commercial Sector of Osun Division, South-Western Nigeria, 1900-1960.” (Ph.D. Thesis, Department of History, University of Ibadan, 2014), 2.

9 . F. Jaekel, The History of the Nigerian Railway, (Ibadan: Spectrum Books Ltd. 1999), 79. This was also established in W. Oyemakinde, "Railway Construction and Operation in Nigeria... 303. See also, A. Olukoju, "Subsidizing the Merchants at the expense of the Administration": Railway Tariff and Nigerian Maritime Trade in the 1920s", in A. Oyebade, (ed.), The Foundation of Nigeria: Essays in Honour of Toyin Falola, (Trenton: Africa World Press Inc. 2003), 373. 
from the consideration of impact of railway in the economic development of America and Europe as well as in the commercial exploitation of Asia in the $19^{\text {th }}$ century. ${ }^{10}$

Railway construction began in December 1895, with a line extending in a northeasterly direction from Lagos. It was initially planned for a wide area, but finance made it to be limited to Osogbo for some years. This was a time when there were no roads except those within the townships. Railway therefore became so prestigious that important Yoruba Obas like Owa of Ijeshaland wrote Governor Macgregor in 1901, entreating him to make the railway pass through his domain and boastfully promised in return to make his people plant whatever crops Lagos wanted for export. ${ }^{11}$ By 1897 , the line had reached Ota, Abeokuta in April, 1899 and Ibadan in December, 1899; a distance of about 123 kilometers from Lagos. The Lagos-Ibadan line was opened on $4^{\text {th }}$ March, 1901. Within the next few years, the line had passed through Yoruba towns in Osun division like, Ede, Osogbo, Ikirun, Inisa and Okuku from where it proceeded to the North. ${ }^{12}$ Scheme of railway operation in and outside Osun Division, extracted from Lagos-Jos thorough passage service is shown below.

\section{Train Timings}

\begin{tabular}{|c|c|c|c|}
\hline \multicolumn{2}{|c|}{ Up (North bound) } & \multicolumn{2}{|c|}{ Down (South bound) } \\
\hline \multicolumn{2}{|c|}{$\begin{array}{l}\text { Lagos (Iddo) dep. } 12 \text { noon } \\
\text { Thursdays }\end{array}$} & \multicolumn{2}{|c|}{ Ilorin arr. 17.53 Monday } \\
\hline Lafenwa arrival & 14.50 & \multicolumn{2}{|l|}{ dep. 18.03} \\
\hline " dep. & 14.53 & Offa arr. & 19.30 \\
\hline Ibadan arr. & 17.30 & „ dep. & 19.39 \\
\hline " dep. & 17.50 & Osogbo arr. & 20.50 \\
\hline Osogbo arr. & 20.42 & „ dep. & 21.00 \\
\hline " dep. & 20.52 & Ibadan arr. & 23.42 \\
\hline
\end{tabular}

10 . D.C. Alfred, Jr. "The Railroads: The first Modern Business Enterprises 1850 s-1860s" in R. Whaples and D.C. Betts(ed.), Historical Perspectives on the American Economy, (London: Cambridge University Press, 1995), .318. Also, see, M. Olaniyan, Economic History of West Africa, 80.

11 . N.A.I CSO 1/1 Vol.47 Confidential Report on the Oshogbo Extension of the Lagos Government Railway, 67/1904, enclosed in Lagos Governor to S. of S. No. 258 of 22 July, 1904.See F. Jaekel, The History of the Nigerian Railway, 13.

12 . N.A.I.-CSO record Group 11-12 Vol.1.A Special list of records on the Nigerian Railway, p. III. 


\begin{tabular}{|lcc|ll|}
\hline Offa $\quad$ arr. & 22.19 & , dep. & 1.56 Tuesday \\
\hline \# dep. & 22.29 & Lafenwa arr. & 4.51 \\
\hline Ilorin arr. & 23.52 & „dep & 4.56 \\
\hline,$\quad$ dep. & 00.03 & Lagos (Iddo) & arr. 7.51 \\
\hline
\end{tabular}

Source: The Nigerian Daily Times, Lagos, Monday, February 5, 1945.

Although the Nigerian Railway Corporation had its pool of skilled and unskilled labor who moved along with the extension of rail line into the hinterland of Nigeria, it succeeded as in other places in introducing waged labor into Osun division. Apart from the few lucky ones who found their ways into the skilled and permanent category, a large number of people provided labor in bush clearing, carrying of exploratory equipment as pre-construction survey continued. Many also served in ground leveling and ballasting, porterage of rail and sleepers. The people were also employed in building railway stations and staff quarters and they also provided post construction maintenance services such as widening of the ways through constant bush cutting, banks increment to specified widths and level and constant watching of bridges for possible repairs among other services. ${ }^{13}$

As envisaged by the British, Railway contributed a great deal to the economic revolution that took place in Yorubaland as in other parts of Africa. ${ }^{14}$ According to Omosini, it had perhaps the greatest impact of any single innovation in transport brought into West Africa from Europe. ${ }^{15}$ Railway stations and quarters began to attract population: Petty traders loitered around railway workers' houses to sell foodstuffs and other necessities. Markets also grew around the stations. For example, Bower market (Oja Bower) was formerly opened in Inisa town on Wednesday $25^{\text {th }}$ May, 1938 after series of interactions between the Station Manager, the Assistant District Officer in Osogbo, District Officer in Ibadan, and the District crown rulers, such as, Akirun of Ikirun, Olobagun of Obagun and Olokuku of Okuku. These rulers were asked to appoint market officials to represent their interests in the market. ${ }^{16}$ The market was meant to ensure adequate supply of cash and food crops from the hinterland to the coast in exchange for European manufactured goods.

13 . R.O. Ekundare, An Economic History of Nigeria 1860-1960, (London: Methuen and Co.Ltd. 1973), 137.

14 . M. Crowther, West Africa under Colonial rule, (London: Hutchinton and Co. Ltd. 1968), 273.

15 . O. Omosini, "Railway Projects and British Attitude towards the Development of West Africa, 1872-1903," Journal of the Historical Society of Nigeria, Vol. 5, No. 4, (June, 1971), 507.

16 . N.A.I., Osun Div. 1/1 107 Railway Department Matters, p.122.Baale of Inisa and Iba were invited. 
New services developed to cater for the interests of these workers. In this category was palm wine tapping, undertaken by the Ila people as a result of its being more profitable to them than working on the railway. ${ }^{17}$ Letters, telegrams, and goods were sent and received through the railway workers. Adjoining towns and villages also regulated their time with stations' clocks. These stations boomed with economic and social activities, and Christian missions made some of them avenues for spreading the gospel. Equally, European mercantile firms utilized them as strategic places to build their stores. All these made the railway stations and quarters to develop into commercial centers for neighboring towns and villages with Station Masters playing the role of economic advisers to the village and town heads. ${ }^{18}$

Osogbo, Ede, Iwo, Ikirun and Inisa developed into urban centers and railway buying stations as shown in the Palm Kernel Export Production Program of 1942-43 below.

\section{Export Production Programme (Palm Kernel) 1942-43 ${ }^{19}$}

\begin{tabular}{|l|l|}
\hline BUYING CENTRES & ALLOCATION (TONS) \\
\hline Odo-Oba & 300 \\
\hline Iwo & 1,000 \\
\hline Ile-Igbo & 650 \\
\hline Ede & 5,200 \\
\hline Osogbo & 7,400 \\
\hline Ikirun & 3,250 \\
\hline Inisa & 150 \\
\hline Okuku & 800 \\
\hline
\end{tabular}

Thus, railway enhanced their prestige vis-à-vis Ogbomoso, Ejigbo and other towns in and out of the division which were quite remote from the railway. ${ }^{20}$ It should be pointed out that, in the old Oyo Empire and throughout the nineteenth century, these towns were not more than insignificant hind towns of Yorubaland. But they quickly emerged into pre-eminence with the advent of the railway. The introduction of railway into Yorubaland, therefore,

17 . W. Oyemakinde, "Railway Construction and Operation", 323.

18 . N.A.I. Osun Div. 1/1 107 Railway Department Matters, p. 122. Also, see W. Oyemakinde, "Railway Construction and and Operation", 323.

19 Source: N.A.I., CSO26:39361, 'Export Production Programme (Palm Produce) 1942-43'. Issued in 4 March 1942. Table 2 shows annual maximum potential production allocated to each center by rail, Abeokuta-Ibadan Districts.

20 . D. Ogunremi, “The Nigerian Motor Transport Union Strike of 1937,” Journal of the Historical Society of Nigeria, Vol. 9, No. 2, (June, 1978), 132. 
made towns to emerge where they did not exist before, while the already existing but very small towns expanded and developed.

In Iwo district, for example, railway line was so constructed that no traditional town lies on it. The trio of Iwo, Ile-Igbo and Kuta are six, three and a half and three miles respectively away from the rail line. However, creation of railway stations in these places resulted into new settlements such as, Yawu, Iwo, Kuta and Ile-Igbo stations along the rail line respectively. These settlements were occupied largely by traders, produce buyers, railway staff and teachers. The presence of a relatively large number of non-farm people equally created markets for food crops. ${ }^{21}$ Railway workers also created credit facility through chain of dealing which they had initiated by buying with promises to pay on their pay day. This often made people to promise one another in turns and thereby making a chain of credits to develop. ${ }^{22}$

\section{Roads}

Between 1906 and 1940, the development of road transportation in Yorubaland featured prominently. Road construction and its concomitant motor transportation resulted into a greater economic revolution than that of the railways. This is because, motor vehicles as means of transportation have a range which far exceeds that covered by the trains. At the initial stage, the desire for road transportation in Yorubaland was due to the need of finding solution to transportation system in a place where tsetse fly made the use of animals of burden impossible. ${ }^{23}$

Also, the construction of roads started from the necessity to build feeder roads for the railways. Roads were designed to provide passengers and cargoes for the newly constructed railway lines. There was also the need to link the interior of Yorubaland with the coast as a way of opening up Yorubaland for economic development. As a matter of fact, the first motorable road in the hinterland of Yorubaland was built in 1906 from Ibadan to Oyo and it was linked to the railways by a railway operated road transport service. After this, motor road services were made available to the public from Ibadan, Osogbo, Ilesa, Ede and Iwo. ${ }^{24}$

21 . O. Adegbola, The Impact of Migration, 14.

22 . W. Oyemakinde, "Railway Construction and Operation", 323.

23 . S.A. Olanrewaju, "The Infrastructure of Exploitation.", 70.

24 . F. Jaekel, The History of the Nigerian Railway vol. 3, p.284. This fact was also established by O.C. Adesina, and A. Olorunfemi, "The Economy of Western Nigeria, 19001980" in, Culture and Society in Yorubaland ed. D. Ogunremi and B. Adediran, (Ibadan: Rex Charles and Connel Publication, 1998), 129. Also, see Ogunjumo, A. "The Political Economy of Transportation Investment in Nigeria, 1884-1945”, Ife Social Sciences Review, Vol. 2, No. 1 (1985), 76-101. 
In Osun division, most colonial roads were constructed through free or voluntary rather than wage labor. And whenever money was provided by the colonial government, it was to complement the effort of the people, hence the fund was usually grossly inadequate. Examples of this abound in the construction of roads like: Iwo-Ejigbo road, Iwo-Ikire road and many others. ${ }^{25}$ Also, several meetings were held by Osun Divisional Finance Committee on how to spend $£ 15,000$ voted by the Regional Government for the improvement of the existing roads and the construction of new ones in Osun Division. ${ }^{26}$ This was because, the money was grossly inadequate.

The foregoing, therefore, made road construction to depend on covee labor throughout the colonial period. Sections of the roads were assigned to laborers from neighboring villages. ${ }^{27}$ Also, while the laborers may be forced in some other parts of Yorubaland as some authors claimed, ${ }^{28} \mathrm{Mr}$. Simeon Fakunle and Mr. Jimoh Afolabi who were among the laborers that constructed IkirunOfa road expressed how enthusiastic they were about the work, because their villages were being opened up. ${ }^{29}$ Such was a period when accessibility to motor transport was regarded by various communities as an important index of progress in the new era.

Demand for road, therefore, became a factor in the native administration politics. And when the administration, invariably for financial reasons, could not meet the insatiable demands for road construction, as it was always the

25 . N.A.I., Osun Div. 1/5 O.G. 192 Iwo-Ejigbo Road, 8.

26 . Osun Div. 1/1 1004 Valhi, Feeder Road Grants, 22.

27 . Oral interviews with, Mr. Simeon Fakunle, a native of Inisa in Odo-Otin Local Government, 87 years and Jimoh Afolabi, a native of Ila-Odo in Odo-Otin Local Government, 85 years $(24 / 06 / 2011)$. The two of them are migrant farmers who are now based in Odigbo, in Odigbo Local Government of Ondo State. They provided the voluntary labour needed for the construction of the road that passed through their villages on Osogbo -Ofaroad. Equally, see A.I. Asiwaju, Western Yorubaland Under European Rule, 18891945: A Comparative Analysis of French and British Colonialism, (London: Longman Group Limited, 1976), 161. Osun Division Annual Reports of 1941, p. 64, equally attested to the above.

28 . J.A. Atanda, The New Oyo Empire, 217 and A.I. Asiwaju, Western Yorubaland Under European Rule, 1889-1945: A Comparative Analysis of French and British Colonialism, 161.

29 . Oral interview, Mr. Simeon Fakunle and Jimoh Afolabi who are natives of OdoOtin Local Government, communal labour was characteristic of all rural African settings, for instance, the same experience was shared about the Ashanti people by S. Heap, S. Heap. "The Development of Motor Transport in Gold Coast, 1900-39", Journal of Transport History, II (1) (September, 1990), according to him, so great was the enthusiasm for road building in Ashanti that, people built their own feeder roads to the trade roads. It was not unusual for villagers to give road engineers a helping hand to demolish houses or cut their ways through farmland, provided the road passed through or near the village. 
case, demanding communities themselves undertook the works. ${ }^{30}$ In this regard, no sacrifice was considered too great to construct roads capable of carrying motor traffic for villages which were in dire need of them. ${ }^{31}$ The great zeal and enthusiasm with which the people of Osun Division participated in road construction was no doubt, an indication of the fact that, they regarded it as a paramount amenity. ${ }^{32}$ On the other hand, the British colonial government placed greater emphasis on roads that led to large palm produce and cocoa growing areas. ${ }^{33}$ Thus, approvals of road construction were usually granted with the hope that such roads would lead to increase in the supply of cash crops. This was the case in the construction of Ara-Ojo and many other roads in the division. ${ }^{34}$

Road construction and maintenance were the responsibilities of the Public Works Department (PWD), established by the central government in 1896. This department co-operated with various native authorities in building major roads in Yorubaland. Majority of these roads were untarred, but they were adequate for the limited number of vehicles available for carrying goods and passengers. Most of these roads came into being by widening and straightening the bush paths and tracks with the use of unskilled village labor generally under the supervision of government officials.

This cooperation between PWD and the people as was also the case in colonial Gold Coast was not unconnected with their realization that pioneer road making was part of their responsibility as farmers if they had to take their produce to the market. As in the case of railways, majority of the roads were built in Yorubaland after preliminary survey by government officials and this was followed by a detailed estimate covering the cost of every item of the work. The use of tender process as used in Gold Coast was sanctioned later by (Sgd.) D.A. Murphy, the acting Permanent Secretary, Ministry of Local

30 . N.A.I. Osun Div. 1/1 1109/4- Touring Note on Ede District 17th- 18th January $1949,6$.

31 . A.I. Asiwaju, Western Yorubaland Under European Rule, 161.

32 . N.A.I, Osun Div. 1/1 1109/4 Touring Notes on Ede District. Jan. 1949, 6.

33 . See Osun Div 1/5 OG.192 Iwo-Ejigbo road, where production of cash crop became a strong reference point in the request for roads construction. Here the petition of Ifeodan people was presented by Elejigbo of Ejigbo to the District officer in July, 1949. The people needed the nine miles road to be constructed from Bode on Iwo-Ejigbo road in order to ease the conveyance of cocoa and palm Kernel that the place was known for.

34 . N.A.I, Osun Div. 1/1 51/9 Annual Report, 1944. p.332. Also in 1905, Governor Egerton argued for the construction of a road between, Osogbo, Ilesa, and Ekiti claiming that, "the country was rich and was expected to export a considerable amount of corn and cotton", see O.O. Olubomehin, "Road Transportation and the Economy of South-western Nigeria 1900-1920" in A. Oyebade, (ed.), The Foundation of Nigeria: Essays in Honour of ToyinFalola, (Trenton: Africa World Press Inc., 2003), 396. 
Government of Western Region in his letter dated $25^{\text {th }}$ May, 1954. This was the case in the construction of the Ede-Ejigbo road, Iwo-Ejigbo road, OkukuOyan, among other roads. ${ }^{35}$

The colonial government designed the construction of trunk roads to run horizontally across the country so as to link the regional capitals and facilitate the movement of goods and services. From 1906, construction of roads continued and before the interruption by the First World War in 1914, a considerable number of them had been built. For example, Osogbo-Ilesa road was constructed in 1911, Osogbo-Ogbomoso road 1912, Osogbo-Ede road $1913 .{ }^{36}$ This trend in road construction was interrupted in 1914 by the First World War which brought about a general reduction in revenue. While the government had little to spend on road construction, the war also brought about a fall in the income of motor transport operators. ${ }^{37}$

However, road construction continued in 1922 with renewed energy. This is because, Europe faced post war problem of finding raw materials to get her industries back to operation as in the pre-war period. ${ }^{38}$ At the end of the Second World War, both regional and local government authorities considerably improved roads in Osun Division by providing more mileage of improved, all-weather roads and by constructing several thousands of additional miles of access roads. This has been an important factor in encouraging the production of export and food crops and their onward movement to their places of need. In spite of all these efforts, by the 1950s, when colonization was nearing its end, a considerable part of Yorubaland was still in need of good roads. ${ }^{39}$

However, the available roads as at 1920 were utilized by the Railway Transport Service and a few indigenous transport operators. Prominent among the private transport operators was W.A. Dawodu of Lagos. Apart from being a dealer and importer, he had vehicles which he used for transport. By 1920, when he extended his mechanic shop to Osogbo, he was not only the largest vehicle importer in Nigeria, but also a builder of motor lorries in the country. At Osogbo, he employed fifty men in his mechanic workshop and had a service of two-ton trucks. ${ }^{40}$ He was later joined in the transport service by oth-

35 . S. Heap. “The Development of Motor Transport”, 30., see also, N.A.I. Osun Div 1/1 51/9 Annual Reports on Ibadan Northern Division 1943.

36 . N.A.I., Ibadan Div. 1/1 Vol. 1, 1253 Osogbo District. This is similar to what transpired in Gold Coast as discussed in S. Heap. "The Development of Motor Transpor", 28.

37 . O.O. Olubomehin, "Road Transportation and the Economy", 398.

38 . Ibid

39 . M. Olaniyan, Economic History of West Africa, 87.

40 . O.O. Olubomehin, "Road Transportation and the Economy", 396, see also O.T. Asabi, The Colonial Administration of Osogbo, 1894-1960. (Unpublished B.A. Long Essay, University of Ibadan, Ibadan, 2004), 37. Also, Olaniyi's claim that, entrepreneurs were among the first set of people to import and operate commercial motor vehicles confirms 
ers like Salami Agbaje of Ibadan, who also had a motor transport company in Osogbo by 1927, Jacob Oparinde, who became the President of the Nigerian Motor Transport Union, Osogbo branch, Bokin and his brother, Adeleke Transports Service, Oloke Transports Service, and a host of others. Although Armels Transport Service also carried passengers, it specialized in transporting mails to the eastern part of the country. ${ }^{41}$

Construction of roads had tremendous effects on the internal trade of Yorubaland. Road transport was generally cheaper than railways and was able to provide door-to-door services which obviated the necessity for loading and unloading at stations as it did in the economy of Gold Coastal about the same time. ${ }^{42}$ The small size of motor in relation to train, often under two tons capacity allowed small loads to be moved profitably and better theft control could be exercised over an individual lorry load than over a long freight train. It, therefore, made it easy for commodities of the country districts to be easily transported to the coast for export and this further encouraged internal production of cash crops. Availability of roads also enhanced distribution of European merchandise in the interior of Yorubaland. It had a considerable effect on both internal and external trade. ${ }^{43}$

\section{Nature and the Associated Diplomacies}

Development of wheeled transportation in Osun Division was associated with several diplomacies. For instance, lateness in road construction was due to the following reasons among others. Since both rail and road were to open up different areas for economic exploitation, railways had no place in places where export crops were not available. ${ }^{44}$ Hence connection of different villages with their district headquarters had to wait till the 1950s. For instance, as at 20 th of June 1955, Odeyinka-Ago-Owu, Ejigbo-Ika-Ayigbiri-Ilobu, Osogbo-Iloba, Gbongan-Owu, Gbongan-Ile-Igbo, Sekona-Tonkere, Ede-Sasa, If-

W.A. Dawodu's prominence in this regards. See R.O. Olaniyi, "Chief D.O. Sanyaolu 18961960: A Yoruba Merchant Prince in Metropolitan Kano", in Journal of French Institute for Research in Africa, Vol. 1 (2005), p. 132.

41 . Oral interview with, Mr. John Afolabi Oparinde, Oparinde's house, Osogbo, 81 years, 06/12/2012. and Mr. Victor Taiwo Babarinlo, 39, Shittu street, Oke Onitea, Osogbo, 72 years, 04/08/2012. According to them, Armels was a Lebanese transport company.

42 . S. Heap, "the Development of Motor Transport", 26. See also, F. Jaekel, The History of the Nigerian Railway, Vol 1, p.9 and, see A. Afolabi, "The Colonial Taxation Policy", 79 .

43 . O.O. Olubomehin, "Road Transportation and the Economy", 398. He expressed it that, as importers of European manufactured goods could reach wider market in the hinterland, so were foodstuffs, like yam cocoyam and vegetables could reach distant markets.

44 . N.A.I. Osun Div. 1/1 Annual Reports of 1944, p. 332. Also, see, G. O. Ogunremi, "The Nigerian Motor Transport", 
on-Ilie, Ogbomoso-Ayegun-Ifeodan, Ikirun-Obagun, Iba-Oyan, Oba-Ilie and Ikire-Iwo roads had not been constructed.$^{45}$ The available roads were meant for maintenance of peace by the British administrative officers and promotion of trade in the division. ${ }^{46}$

Although both the rail and road systems of transportation were meant for the conveyance of goods needed by the colonial government and firms to the coast, it equally became an avenue through which items of local trade and articles of indigenous trade were conveyed to their places of need and through which European products got to the people in their different villages ${ }^{47}$ With this development, human porterage which was seen as the pillar of the economy in Osun Division, where neither canoes nor pack animals existed, began to lose its importance. ${ }^{48}$

Also, the new means of transportation were not put in place so that Africans could visit their friends. They were not constructed to facilitate internal trade in African commodities. There were no networks of roads connecting different parts of Osun Division in a manner that make sense with regard to Africans' needs and development. They were impelled by British political, economic and strategic imperatives. ${ }^{49}$ Both the roads and railways led down to the sea as a way of tapping the resources of the interior of Yorubaland for the need of the British home industries. In other words, any catering for African interests was purely coincidental and transportation remained labor intensive in most parts of the division throughout the colonial period. In the words of Walter Rodney, these facilities were nothing more than infrastructures for underdevelopment. ${ }^{50}$

Moreover, where roads were available, they were amazingly small and in bad condition and this constituted a major problem for commerce in the division. ${ }^{51}$ A good example here was the experience of the cooperative mem-

45 . All these roads were parts of the new roads recommended for construction in the memorandum submitted by the Road Development Committee of Osun Division to the Regional Road Development Committee in June 1955. See N.A.I. Osun Div. 1/1 1004 Vol. II, Feeder Road Grants, Osun Division, 71.

46 . W. Rodney, How Europe Underdeveloped Africa, (Dar-es-Salaam: Tanzania Publishing House, 1972), 228.

47 . N.A.I. Osun Div. 1/1 1004 Vol. II, Feeder Road Grants, Osun Division, 4.

48 . D. Ogunremi, "Human Porterage in Nigeria in the Nineteenth Century- A Pillar in the Indigenous Economy", Journal of the Historical Society of Nigeria, Vol, 8, No. 1, (December, 1975), 55.

49 . E.A. Walker, "British Colonialism and Economic Transformation", in, A. Oyebade, (ed.), The Foundation of Nigeria: Essays in Honour of Toyin Falola, (Trenton: Africa World Press Inc. 2003), 248.

50 W. Rodney, How Europe Underdeveloped Africa, 228.

51 . N.A.I. Osun Div. 1/1 Osun Division Annual Report, 1956, See also F. Jaekel, The History of the Nigerian Railway, Vol.1, 83. 
bers in Iwo, who were willing to link up with railway station where they had a grading store. In the report of the Assistant Registrar of cooperative societies, Ibadan to the Senior Divisional Adviser to the Division Officer of Osun Division, Osogbo, the bad road was responsible for the society's loss of over twenty pounds annually due to the excessive transport cost. ${ }^{52}$

As a result of the foregoing, human porterage became an inevitable complement of road transportation. For example, absence of network of roads among different villages in the districts of the division made human porterage to remain the only alternative in some places. ${ }^{53}$ Thus, it became the means of transportation of goods on short distances. In long distance trade, articles were carried, using members of the household of the traders or hired carriers (Daruke system) to junctions or places where the articles would be conveyed by lorry to their places of needs and vice versa. ${ }^{54}$ This coexistence of both the old and new forms of transportation continued until after the colonial era. For example, people of Odo-Otin, Ifelodun among other parts of Osun Division had to depend on head porterage, since most of the roads and bridges linking them with their district headquarters were constructed in the late 1930s and early 1940 s. $^{55}$

With this combination of road with head porterage system, some of the challenges associated with human porterage were either surmounted or reduced. For instance, high cost of transportation of the era of total dependence on human porterage both on a short- and long-distance trades was reduced. ${ }^{56}$ This was due to the increase in the supply of goods and services as a result of better carrying capacity of lorries, which took over transportation of foods and services on long distances. Since men now have to carry articles of trade on short distances, their carrying capacity improved beyond the pre-colonial 60-70 lbs3 per man. ${ }^{57}$ Equally, the cost of feeding and other forms of remuneration of carriers became reduced and these had a positive impact on the cost of goods they carried and the services they rendered.

Women still predominated in carriage service and household labor. In this part of Yorubaland, a family of numerous children was still a source of opulence and prosperity. Men devoted so much time to land cultivation and other

52 . N.A.I. Osun Div. 1/1 Osun Division Annual Report, 1956, 20.

53 . D. Ogunremi, "Human Porterage", 39.

54 . I.A. Akinjogbin, "The Economic Foundation of the Oyo Empire", in I.A. Akinjogbin and S.O. Osoba (eds.), Topics on Nigerian Economic and Social History, (Ile-Ife: University Press Limited. 1980), 50.

55 . N.A.I. Osun Div. 1/1 Annual Reports on the Northern Districts of Ibadan Division, $1942,12$.

56 . N.A.I. Osun Div. 1/1 1004 Vol. II Feeder Road Grants, Osun Division, 21.

57 . D. Ogunremi, "Human Porterage". 51. 
jobs that they had no time for either carriage job or going to market. Both jobs came to be regarded as occupations suitable only for women and children. Thus, it became a division of labor by sex and age. ${ }^{58}$ However, since the scale of production still remained small, this age-long system of transportation was still relevant and adequate for the economy.

\section{Railway}

Railway construction witnessed irregular supply of the construction materials owing to shipping problems and the difficulty in the Lagos harbor. Also, much labor was required in carrying the sleepers from Lagos and ballast from Abeokuta quarry for use along the lines in the hinterland. All these, handicapped the progress of the construction of the railway in the hinterland of Yorubaland, particularly, in Osun Division..$^{59}$ Moreover, the mix reactions of the Yoruba people in relation to the provision of the wheeled transport was equally a great challenge to the colonial government. As the government was bent on maintaining her colonies with minimum cost, it decided to construct a line of railway for easy transportation of goods from the hinterland to the coast and for administrative purposes, such as sending troops at once to possible rebellious groups. The construction was confronted with different reactions. While some people refused the construction of railway on their farmlands and some other sacred locations, many others bombarded the office of Railway Extension Survey Party with requests for construction of railway across their territories. For instance, while the Alaafin of Oyo did not allow railway to pass through Oyo so as to ensure adequate preservation of Yoruba culture, various railway stations in Osun Division, such as Inisa, Ede, Origo, Yawu, Ile-Ogbo, Kuta and Iwo stations were all created on requests by the people. ${ }^{60}$

For instance, Ede station was established after an appeal was made by the Timi of Ede to the General Manager of Nigerian Railway that the station served a large area comprising Ogbomoso, Ejigbo, Ede, Ife, Edun-Abon and Gbongan districts. ${ }^{61}$ He pleaded that Kano trains should be stopping at Ede to pick up and discharge passengers when going to and coming from the Northern Province. However, to the traffic inspector of the Nigerian Railway corporation, such requests could not just be granted, because, twelve people's

58 . Oral interview with Prince I.A. Oyebamiji, Babakekere of Olokuku, 85 years, $06 / 10 / 2012$. He is the head of Oluronke's ruling house (The current ruling house in Okuku)

59 . W. Oyemakinde, "Railway Construction and Operation", 323.

60 . N.A.I. CSO 1/1 Vol. 47, Confidential Reports on the Osogbo Extension of the Lagos Government Railway, 67/1904, enclosed in Lagos Governor to S. of S. No. 258 of 22nd July, 1904. For the list of the railway halt stations in Osun Division above see, F. Jaekel, 1999, The History of the Nigerian Railway, Vol. 2, and p.21.

61 100. N.A.I. Osun Div. 107, Railway Department Matters, 181. 
booking at Ede and even lesser in Ikirun as at July, 1935 did not justify service by limited train. ${ }^{62}$

In his letter of $12^{\text {th }}$ March, 1947 to the District Officer of Northern Districts of Ibadan Division at Osogbo, Timi of Ede, Adetoyese Akangbe (1945-1974) complained that traders of Ife, Edun-Abon and Ejigbo were experiencing difficulty in booking their goods and joining trains In Osogbo. The traders themselves expressed resentment on their waiting to entrain in Osogbo with unnecessary delay to obtain tickets. Many of them suffered great losses as they often had to return home after failing to board train, as a result of the unnecessary delay at the ticket counter in Osogbo. ${ }^{63}$

Eventually, inflexibility of the rail line created a dependency situation between the towns with railway stations and those that are not on the rail line. For instance, people as far as Ogbomoso, Ejigbo and Origbo areas depended on Ede station for transportation up north and down south with their produce. ${ }^{64}$ Most of these towns and villages were connected with footpaths along which the people head-loaded their goods to the railway stations. However, most of these footpaths were eventually expanded to become feeder roads, which enhanced effective functioning of railway system in the division. For instance, places in the nearby and faraway places, such as Ilesa, Ondo and Ekiti districts, depended on Osogbo for rail transportation. In the 1920s, a considerable quantity of cocoa railed from Osogbo emanated from Ilesa. ${ }^{65}$ Also, as at 1920, cotton was being taken by road from Ekiti districts to the agents of the British Cotton Growing Association (BCGA) in Osogbo. ${ }^{66}$

Railway system also involved theft. For instance, sixteen guinea fowls of Mr. I.B. Abileye were reported stolen in Dan Kano train during a standstill in Osogbo on $3^{\text {rd }}$ September, $1940 .{ }^{67}$ Also, there were complaints of discrimination against some goods, especially those that were not needed by the Europeans at the coast. Notable in this regard was the complaints by the Ikirun kolanut dealers, that their merchandise was being delayed considerably in transit to Kano. This was conveyed to the District Officer at Ibadan by the traffic inspector of the Nigerian Railway in his letter of $4^{\text {th }}$ March, $1947 .^{68}$

In addition, rail transportation was grossly expensive. For instance, as at 1920 , the rate for rail transport was 10 pence per mile. This made colonial

62 . Ibid, 178.

63 . Ibid, 178.

64 . Ibid, 178

65 . A.Olukoju, "Subsidizing the Merchant," 381.

66 . O.O. Olubomehin, "Road Transportation and the Economy", 396.

67 . N.A.I. Osun Div. 107, Railway Department Matters, 50.

68 . Ibid, 179. 
government to see it as a panacea for economic ills of Nigeria. ${ }^{69}$ It therefore, became clear that motor transportation attracted more produce to the Lagos market than railway. This was because it was cheaper to convey produce by road than by railway. It was observed by the Lagos Chamber of Commerce that railway was discouraging agricultural production through high rates, while construction of more roads and decreasing costs of road transportation encouraged production. ${ }^{70}$

\section{Impact of the Wheeled Transportation Technology on Osun Division}

Wheeled transportation was an important attribute of the colonial period, it served as a medium through which the colonial economic order was established. It was indeed a period of economic revolution. Although cash crops were the targets of the new economic orientation, trade in food

crops and other indigenous merchandise witnessed a tremendous expansion. This had a positive impact on the standard of living of the people in the division. Apart from the employment opportunities that the new economic orientation generated, people's purchasing power was improved. Hence, colonial demands boosted indigenous production. At about this period, available records showed that trade in local articles thrived over and above cash crops. For example, it was an excellent period for farm crops like kolanut, yam and fruits for which the division was known. Kolanut trade from Osogbo, Ede, Ikirun and Odo-Otin to the North also thrived. ${ }^{71}$

This would not have been possible without the railway, which had traversed Osun Division since the first decade of the twentieth century. The division had eight railway stations in: Iwo, Ile-Ogbo, Origo, Ede, Osogbo, Ikirun, Inisa and Okuku respectively. These towns became commercial centers out of which Osogbo was the most important. As mentioned earlier, the railway necessitated the construction of feeder roads. This development, as well as the roads constructed to link the different districts with the divisional headquarters, provided a serene environment for increasing agricultural specialization, which must have yielded dividends in term of rising productivity that enhanced the development of both local and international trade in the

69 . O. Omosini, "Railway Project and British Attitude Towards the Development of West Africa, 1872-1903," Journal of the Historical Society of Nigeria, Vol. 5, No. 4, (June, 1971), 493.

70 . A. Olukoju, "Subsidizing the Merchant" 384.

71 . N.A.I., OsunDiv 1/1 51/9 Annual Reports on Northern Districts of Ibadan Division, 1941, 20. 
division. ${ }^{72}$ As a matter of fact, Osun Division was placed at a great advantage in relation to other neighboring divisions as shown in the data below:

Table 3: Division Agricultural Yields ${ }^{73}$

\begin{tabular}{|l|l|l|}
\hline Divisions & Cocoa & Palm Kernels \\
\hline Osun Division & 5,300 tons & 9,905 tons \\
\hline Ilesa Division & 2,822 tons & 5,665 tons \\
\hline Ife Division & 6,786 tons & 4,401 tons \\
\hline
\end{tabular}

The figures given for Osun Division exclude produce from Iwo and Ogbomoso Districts, which were large produce areas. If both districts are added to the figures above, produce from Osun Division will double those of Ife and Ilesa Divisions. ${ }^{74}$ The improved transportation equally facilitated the movement of valuable products from Osun Division to Lagos, from where they were shipped to Britain and a few other European countries. For instance, railway shipment of yams from Osogbo, Ede and Ikirun stations showed that between May and August of 1942, 1,456 tons had been conveyed out of the area. $^{75}$

As in other parts of Yorubaland, the foregoing economic opportunities created were quickly utilized by the trading companies whose direction of expansion depended initially on availability of palm produce, cocoa and adequate means of transportation. Osogbo, the capital, was found most suitable in the division for European commercial expansion into the hinterland. Hence, it served as a hub for the neighboring Ife-Ijesa and Ondo Divisions. In their pursuit of the promotion of peaceful commerce in the hinterland of Yorubaland, seven of the firms had established branches at Osogbo by $1909 .{ }^{76}$ These were Paterson and Zochonis, G.L. Gaiser, W. B. MacIver \& Co., John Holt, the Lagos Stores, Witt \& Bush, Miller Brothers, G.B. Ollivant, A.J. Tangalakis, Gottschalk and United African Company (U.A.C.) which was formed through the merger initiated by the Lever Brothers. These firms were also joined by a

72 . J.A. Atanda, The New Oyo Empire, 232.

73 Source: Secretary of Osun Divisional Council to the Permanent Secretary, Ministry of Local Government, Western Region Ibadan, 8 October, 1954 (N.A.I Osun Div. 1/1 1004/II Town and District Roads Osogbo District, p. 21.

74 . N.A.I., OsunDiv 1/1 1004/II Town and district roads Osogbo District, 1954, 21.

75 . N.A.I. Osun Div. 1/1 51/9 Annual Report on Northern Districts of Ibadan Division, $1942,377$.

76 . A. Olorunfemi, The Export Trade of South-Western Nigeria, 1900-1950: A Study in the Economic Development of the Yoruba Country. (Unpublished M.Phil. Thesis, University of Ife, Ile-Ife, 1972), 29. 
number of Lebanese and Indian traders to dominated trade in the division from 1920s. The cumulative effect was the considerable growth of Osogbo population as indicated in the table below:

Table 1: Population Growth of Osogbo (1911-1963) ${ }^{77}$

\begin{tabular}{|l|l|c|}
\hline Year & Population & Percentage increase \\
\hline 1911 & 59,821 & -- \\
1921 & 76,576 & $28 \%$ \\
1931 & 98,024 & $28 \%$ \\
1952 & 164,639 & $68 \%$ \\
1963 & 251,674 & $53 \%$ \\
\hline
\end{tabular}

As a matter of fact, economic recovery of the World War II era, after a long depression since 1930s lifted the price level and elevated the confidence of workers and farmers alike. The war witnessed a high demand for agricultural products in the metropolitan factories. Wheeled transportation also facilitated the people's contribution to war efforts during the Second World War as they were made to donated food crops and money to various War Relief Funds. ${ }^{78}$

The new transportation system also occasioned mass emigration of people from the division, first to Lagos, Ijebu, Egba, Ife, Ondo and later to faraway places like Benin Republic, Togo, Ghana, Abidjan and other West African countries. Although records show that people have been moving to these areas before 1900, the number was very negligible. ${ }^{79}$ Following the British occupation of Nigeria in 1900 and their dire need for cash crops, different agricultural centers were established in Lagos and Egba areas. ${ }^{80}$ Since the British authority had outlawed slave labor in 1901 and pawnship early in the $20^{\text {th }}$ century, there arose an acute shortage of labor which culminated into the emergence of wage or paid labor which migrants from Oyo province, particularly Osun Division provided. Hence, people from different parts of Nigeria, such as the Hausa, Sobo, Ekiti, Ebira, Agatu, Idoma and Oyo Yoruba of which Osun Division is a part migrated to these areas where they worked in some

77 Source: Federal Office of Statistics (1980).

78 . N.A.I. Osun Div.1/1 51/ IX Annual Report on the Northern District of the Ibadan Division, 1944, 329.

79 . S.O. Osoba, “The Phenomenon of Labour Migration”, 520.

80 . B.A. Agiri, "The Development of Wage Labour in Agriculture in Southern Yorubaland, 1900-1940,” Odu, No. 37, (January, 1990), 39. 
of the big farms before they either established farms of their own or ventured into other businesses. ${ }^{81}$

People of Osun Division formed the majority of the employees of the various farm settlements in the areas mentioned above. This is because, as modern transportation reached their towns or passed closed to it, they utilized its advantages by migrating to Lagos and its environs. For example, with the completion of the Ibadan- Oyo-Ogbomoso motor roads and the inauguration of a lorry service on it by the Lagos Government in 1906, many Ogbomoso people migrated to Lagos in search of employment. In a similar vein, the extension of railway to Osogbo in 1907 facilitated emigration from Osogbo, Ikirun, Iree, Eripa, Iwo, Ogbaagba, Ile-Ogbo, Kuta and Ejigbo. From the southern part of Yorubaland, majority proceeded to Benin Republic, Togo, Ghana, Cote d'Ivoire and other parts of West Africa. Ejigbo, Ede and Iwo people concentrated in Togo and Abidjan, while people from Ogbomoso concentrated in Ghana and Northern Nigeria. ${ }^{82}$

Since Osun Division lies in the savanna region of Nigeria with pockets of rain forest, it therefore had little opportunities for improving standard of living compared to the adjoining divisions, such as, Ife and Ijesa. ${ }^{83}$ As a result of this, the people of the division were bound to migrate to other places where means of improving livelihood abound in large quantity. The foregoing accounted for reasons why the people of the division were highly involved in long distance trade. ${ }^{84}$

\section{Conclusion}

From the foregoing, it has become glaring that the introduction of mechanized transportation had a multiplier effect on the commercial activities of Osun Division. This is because the new economic orientation it ushered in culminated in the provision of basic infrastructures that enhanced exploitation of the resources of Osun and the adjoining divisions of Ife-Ijesa and Ondo. For example, various towns and villages were opened up to the world economy by the network of roads and railway that were constructed to facilitate trade. However, as the people took to the production of crops needed by the Europeans as a way of making case for their own needs of modern transportation system, their economy got incorporated into the British capitalist economy.

81 . Ibid, 38 .

82 . O Adegbola, The Impact of Migration, 6.

83 . Ibid, 10.

84 . Ibid, 5. 
The coming of the European trading firms also resulted into loss of independence by the indigenous entrepreneurs. Hence, they became subservient to the European trading firms. Those who had earlier served as middlemen between the division and Ibadan and Lagos expanded the scope of their trading activities, while smaller and several petty traders emerged, especially in the outlying districts of Osun Division. However, it needs to be pointed out here that, although cash crops were the concern of the European firms, trade in food crops expanded greatly in the colonial Osun Division. Evidence of these abound in the importance attained by Odo-Otin and its environ as a result of its supply of yams, both as a contribution to "winning the war effort" and to the Lagos community in the colonial period. While trade in cash crops dropped in this area in the 1950s, trade in kolanut and food crops from Ikirun and Odo-Otin to the North thrived greatly during the same period.

However, of all the agents of change in the Yoruba indigenous commercial sector, the British transportation projects, particularly the wheeled transportation system was the most important. ${ }^{85}$ First in this regard was the railway. Coupled with the construction of roads, which were necessary for effective functioning of the railway systems, the transportation system was revolutionized. ${ }^{86}$ By 1933, all the major towns of Osun Division which later became headquarters of districts were connected by roads and the system of head porterage over long distances and movement of caravan along footpaths was almost at an end. Human porterage therefore, became confined to villages where roads were yet to be constructed. Thus, movement of farm produce from farms to the villages and subsequently to the major towns no longer depended solely on human porterage. At least, the foundation for a modern transport system had been laid. ${ }^{87}$

85 . O. Oshin, "Nigerian Railways under Stress, 49.

86 . E.A. Walker, "British Colonialism and Economic Transformation," 248, See also, O.O. Olubomehin, "Road Transportation and the Economy", 393.

87 . J. A. Atanda, The New Oyo Empire, 219. 